\title{
Breast Lump Palpated
}

National Cancer Institute

\section{Source}

National Cancer Institute. Breast Lump Palpated. NCI Thesaurus. Code C137946.

Palpation exam confirms presence of a breast lump. 